\title{
Hull, McCarthy, and Spaepen Are 1990 MRS Fall Meeting Chairs
}

\section{Program Will Cover Traditional and New Areas}

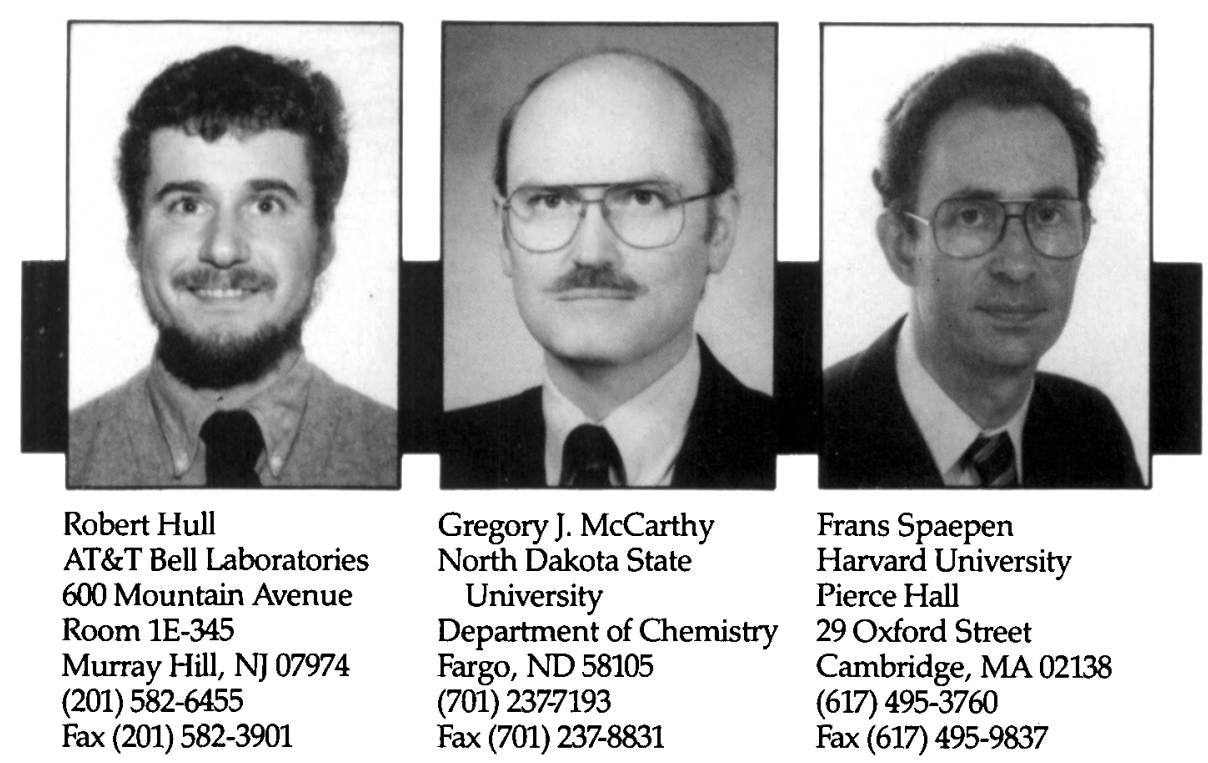

Robert Hull, Gregory McCarthy, and Frans Spaepen will serve as meeting chairs for the 1990 MRS Fall Meeting to be held November 26 - December 1, 1990 in Boston Massachusetts. "At this meeting," said Robert Hull, "we intend both to cover those topics which represent the traditional strengths of the Materials Research Society-including semiconductor epitaxy, ion implantation, ceramic superconductors, clusters, polymers, and cementsand to include symposia on areas which are newer to MRS, such as emerging analysis techniques and microlithography."

Greg McCarthy and Frans Spaepen, who bring to this meeting considerable experience in symposium organization, expressed their commitment to maintaining and enhancing the quality of MRS meetings. McCarthy's goal is to see that the full range of materials is represented. Spaepen pledged that this meeting will "foster interdisciplinarity and high scientific standards, pay attention to all types of materials, and provide a forum for both 'regulars' and newcomers."

Topics and organizers have already been selected for 24 technical symposia, and the call for papers will be published in March 1990. The deadline for one copy of each abstract to be received at MRS headquarters is July 1, 1990. A full complement of short courses will also be offered as well as an equipment exhibit and job placement center.

Robert Hull is a member of the technical staff in the physics research division of AT\&T Bell Laboratories at Murray Hill, New Jersey. His research interests include nucleation and growth phenomena in semiconductor heteroepitaxy; experimental and theoretical studies of strain relaxation kinetics in lattice-mismatched epitaxy via misfit dislocation nucleation, propagation and interaction; atomic-scale structure of interfaces, precipitation and growth processes in metal silicide and germanide structures formed by ion implantation; and quantification of high resolution transmission electron microscopy images. He received his $\mathrm{PhD}$ in materials science from Oxford University, England in 1983 and worked at. Bell Laboratories on a postdoctoral position and at Hewlett Packard Research Laboratories before joining Bell Laboratories full-time in 1987. Hull, an MRS member, has previously co-chaired MRS symposia on the Initial Stages of Epitaxial Growth (1987) and Heteroepitaxy on Silicon (1988).

Gregory J. McCarthy is professor of chemistry and geology at North Dakota State University in Fargo and was previously a research associate professor at
Penn State's Materials Research Laboratory. McCarthy has active research programs in analytical $x$-ray diffraction, application of solid state chemistry and geochemistry to the utilization or disposal of inorganic wastes from coal combustion and gasification, hydraulic reactions in silicates and aluminosilicates, and mineralogy and geochemistry in soil environments. His Penn State research included studies of catalysts and crystalline ceramic nuclear waste forms. McCarthy is a fellow of AAAS, a member of the American Chemical, Crystallographic and Ceramic Societies, the Mineralogical Society of America, and MRS, and is currently serving as past-chairman of JCPDS-International Centre for Diffraction Data. He is also program chairman of the Pacific International Congress on X-Ray Analytical Methods to be held in 1991.

Frans Spaepen is currently Gordon McKay Professor of Applied Physics at Harvard University. He received an undergraduate degree in metallurgy from the University of Leuven, Belgium, in 1971 and a PhD in applied physics from Harvard in 1975. He has been at Harvard first as an IBM Research Fellow until 1977 and from then on as a faculty member. His research interests include phase transformations, atomic transport, and mechanical properties of amorphous metals and semiconductors; the production, diffraction, stability, and mechanical properties of artificial multilayers; the structure of amorphous-crystalline interfaces and grain boundaries and the structure and transformations of quasi-periodic crystals.

$\mathrm{He}$ is a member of MRS, AIME, ASM, APS, and the Bohmische Physikalische Gesellschaft. He was chairman of the 1988 Gordon Conference on Physical Metallurgy, and is on the Advisory Editorial Board of Journal of Non-Crystalline Solids. He co-chaired MRS symposia on Multilayers (1987) and Phase Transformations in Condensed Systems(1985) and was recently elected to serve as an MRS councillor. 


\section{Boston, Massachusetts November 26- December 1, 1990 \\ 1.9.9.0 \\ Abstract deadline: July 1, 1990}

- SYMPOSIUM A / SURFACE CHEMISTRY AND BEAM-SOLID INTERACTIONS Harry A. Atwater, Caltech, (818) 356-2197 Frances A. Houle, IBM Almaden Research Center, (408) 927.2420

Doug Lowndes, Oak Ridge National Laboratory, (615) 5746306

\section{- SYMPOSIUM B / ELECTRONIC, OPTI-} CAL AND DEVICE PROPERTIES OF LAYERED STRUCTURES

John Hayes, Bellcore, (201) 758-2851

Mark Hybertsen, AT\&T Bell Laboratories, (201) 5823628

Eicke Weber, University of California, (415) 642-0205, FAX (415) 486-5933

- SYMPOSIUM C / MICROSTRUCTURAL EVOLUTION OF SURFACES AND THIN FILMS

Carl V. Thompson, Massachusetts Institute of Technology, (617) 253.7652

Jeffrey Y. Tsao, Sandia National Laboratories, (505) 844.7092

David Srolovitz, University of Michigan, (313) 936-1740

- SYMPOSIUM D / ELECTRONIC PACKAGING MATERIALS SCIENCE Edwin D. Lillie, MCC, (512) 250-2715 Kenneth A. Jackson, AT\&T Bell Laboratories, (201) $582-4188$

Ralph J. Jaccodine, Lehigh University, (215) 758-4409

- SYMPOSIUM E / CHEMICAL PERSPECTIVES OF MICROELECTRONIC

\section{MATERIALS}

Mihal E Gross, AT\&T Bell Laboratories, (201) 582-4504 Lawrence H. Dubois, AT\&T Bell Laboratories, (201) $582-7920$

Leonard V. Interrante, Rensselaer Polytechnic Institute, (518) 276-2644

Klaus F. Jensen, Massachuselts Institute of Technology, (617) 253-4589

\section{- SYMPOSIUM F / PHASE TRANSFOR- \\ MATIONS \\ Michael O. Thompson, Cornell University, (607) $255-4714$}

- SYMPOSIUM G / CLUSTERS \& CLUSTER-ASSEMBLED MATERIALS Robert S. Averback, University of Illinois-Uibana, (217) $333-4302$

David L. Nelson, Office of Naval Research, (202) $696-4410$

J. Bernholc, North Carolina State University, (919) 737.3126

\section{- SYMPOSIUM H / HIGH-TEMPERATURE} SUPERCONDUCTORS

Kenneth Lay, GE Corporate Research and Development Center, (518) 387-7495 Julia M. Phillips, AT\&T Bell Laboratories, (201) $582-4428$

Allen Goldman, University of Minnesota, (612) 624-6525

Anthony C. Schaffhauser, Oak Ridge National Laboratory, (615) 574-4826
- SYMPOSIUM I / MECHANICAL PROPERTIES OF POROUS MATERIALS Lorna J. Gibson, Massachusetts Institute of Technology, (617) 253-7107

Karl Sieradzki, The Johns Hopkins University, (301) 338-5409

David Green, Pennsytvania State University, (814) $863-2011$

\section{- SYMPOSIUM J / ADVANCED DIFFRAC.} TION METHODS

Philip I. Cohen, University of Minnesota, (612) 625-5517 David Eaglesham, AT\&T Bell Laboratories, (201) 5823768

Ting C. Huang, IBM Almaden Research Center (408) $927-2375$

\section{- SYMPOSIUM K / DEFECTS IN}

MATERIALS

Paul D. Bristowe, Massachusetts Institute of Technology, (617) 253-3326

Ernst Epperson, Argonne National Laboratory, (312) $972-4971$

J.E. Griffith, AT\&T Bell Laboratories, (201) 582-5222

Z. Lillienta-Weber, University of California Benkeley, (415) $486-6276$

\section{- SYMPOSIUM L / SOLID STATE IONICS} Gholamabbas Nazri, GM Research Laboratory, (313) 986-0737

Duward F. Shriver, Northwestern University, (312) $491-5655$

M. Balkanski, Universite Pierre et M. Curie, France Robert A. Huggins, Stantord University, (415) 723-4110, FAX (415) 725-4034

- SYMPOSIUM M / KINETICS IN SMALL CONFINING SYSTEMS

J.M. Drake, Exxon Research and Engineering, (201) $730-2848$

R. Kopelman, University of Michigan, (313) 7647541 J. Klafter, Tel Aviv University, Israel, 972-3-5450254, FAX 972-3-541-3752

\section{- SYMPOSIUM N / COVALENT}

\section{CERAMICS}

Gary Fischman, Alfred University, (607) 871-2449

Richard M. Spriggs, Alfred University, (607) 871-2486

\section{- SYMPOSIUM O / FIBER-REINFORCED} CEMENTTTIOUS MATERIALS

Sidney Mindess, University of British Columbia, (604) 2286413

Jan P. Skalny, W.R. Grace \& Company, (301) 531-4597

- SYMPOSIUM P / SCIENTIFIC BASIS FOR NUCLEAR WASTE MANAGE-

\section{MENT XIV}

T. Abrajano, Jr, Argonne National Laboratory, (312) $972-4261$

Lawrence H. Johnson, Whiteshell Nuclear Research Establishment (204) 753-2311

- SYMPOSIUM Q / HIGH-TEMPERATURE ORDERED INTERMETALLIC ALLOYS James O. Stiegler, Oak Ridge National Laboratory (615) $574-4065$

David P. Pope, University of Pennsytvania,

(215) $898-7246$

James C. Williams, GE Aircraft Engines, (513) 243-4531
- SYMPOSIUM R / NOVEL STRUCTURAL AND ELECTRONIC PROPERTIES OF POLYMERS

Joon Row, University of Cincinnati, (513) 556-3117 John M. Torkelson, Northwestern University, (312) $491-7449$

John Emerson, AT\&T Bell Laboratories, (609) 639-2571

- SYMPOSIUM S I SYNTHESIS AND PROPERTIES OF NEW CATALYSTS: UTILIZATION OF NOVEL MATERIALS COMPONENTS AND SYNTHEIIC TECHNIQUES

Marc J. Lodoux, Universite Louis Pasteur Strasbourg I, France

Edward W. Corcoran, Excon Research and Engineering, (201) 730-2465

Jack R. Knox, Knox Consulting Company (312) 357.3707

- SYMPOSIUM T / LONG-WAVELENGTH SEMICONDUCTOR MATERIALS Avishay Katz, AT\&T Bell Laboratories, (201) 582-2261 Robert M. Biefald, Sandia National Laboratories, (505) 8441556

R.J. Malik, AT\&T Bell Laboratories, (201) 5826580 Robert L. Gunshor, Purdue University, (317) 4943509

- SYMPOSIUM U I ADVANCED TOMOGRAPHIC IMAGING METHODS FOR

THE STUDY OF MATERIALS

J.L. Ackerman, Massachusetts General Hospital, (617) 7263083

W. Ellingson, Argonne National Laboratory, (312) $972-5068$

- SYMPOSIUM V / BIOMATERIALS (Chairs to be announced)

- SYMPOSIUM W / DYNAMICS OF DISORDERED SYSTEMS AND FRACTALS James P. Stokes, Excon Research and Engineering, (201) $730-2426$

Mark O.Robbins, Johns Hopkins University

(301) $338-7204$

T.A. Witten, University of Chicago, (312) 702-0947; FAX (312) $702-5863$

\section{- SYMPOSIUM X / FRONTIERS OF} MATERIALS SCIENCE

Rustum Roy, Pennsytvania State University, (814) $865-3421$

- SYMPOSIUM Y I QAUNTUM STRUCTURES \& MICROLTTHOGRAPHY T.P. Smith III, IBM T.J. Watson Research Center, (914) 945-2809

D. Kerns, IBM T.J. Watson Research Center (914) $945-1147$

S.D. Berger, AT\&T Bell Laboratories, (201) 582-2484 H. Craighead, Comell University, (607) 255-2329

\section{MEETING CHAIRS}

Robert Hull, AT\&T Bell Laboratories, (201) $582-6455$

Gregory McCarthy, North Dakota State University (701) 237.7193

Frans Spaepen, Harvard University (617) 4953760 